\title{
Study of Egyptian Cotton to Alternative Irrigation Systems with NPK Rates and Frequencies Under Two Planting Dates
}

El-Sayed, A.E.M. ${ }^{2}$; E.M.M.Shalaby ${ }^{1}$; W.M. El-Shazly ${ }^{2}$ and M.T. Said ${ }^{1}$

${ }^{1}$ Dept. of Agronomy, Fac. Agric., Assiut Univ., Egypt

${ }^{2}$ Cotton Res. Inst., Agric. Res. Centre, Giza, Egypt

Received on: $12 / 5 / 2016$

Accepted for publication on: 6/6/2016

\section{Abstract}

Six separate field trials were conducted at Shandaweel Agric. Res. Station (Sohag governorate), Egypt during 2012 season and repeated in 2013 season to study the effect of a new irrigation method with NPK rates and frequencies under two planting dates on yield and yield component of Egyptian cotton variety Giza90. The obtained results revealed that sowing dates affected significantly all studied characters due to the variation in total amount of heat units in each date. Early planting date in March increased yield and its component (number of sympodia branches/plant, number of open boll/plant, boll weight, seed cotton yields/plant and fed.) in both seasons. In the first season, a new irrigation method, i.e. alternative irrigation system resulted the high mean values for number of sympodia/plant, number of open boll, boll weight, yields per plant and per fed. in the first planting date, but in the second date recorded high mean values for number of open boll and yield per plant. Moreover, in the second season appearance high mean values for number of open boll in the first planting date and number of sympodia/ plant, number of open boll and seed cotton yield per plant in the second planting date. Application of NPK fertilizer up to high rate $125 \%$ from the recommended NPK/fed. significantly increased number of sympodia/ plant, boll weight and seed cotton yield per fed. under the two planting dates in both season. On the other hand, 100\% from the recommended NPK/fed. recorded high mean values for number of open boll and seed cotton yield per plant in the both seasons for each planting date. Splitting fertilizers five times led to increase thenumber of sympodia/plant, boll weight and seed cotton yield per fed. in the first planting date for 2012 and 2013 seasons as well as, number of sympo$\mathrm{dia} /$ plant, seed cotton yield per fed. and number of sympodia/plant, number of open boll in 2012 and 2013 seasons respectively, for the second planting date compared with the other treatments.

Keywords: Cotton, Planting date, Irrigation, Fertilization, Splitting fertilizers, Yield and yield component.

\section{Introduction}

Cotton (Gossypium barbadense L.) is considered the main fiber crop through industry in Egypt as well as the world. Therefore, all efforts should be continued to improve its quality and quantity of it either through cultural methods or breeding programs. For some economic factors occurred in Egypt such as cooperative marketing, high wages of laborers and high prices of cereals when compared with cotton led to a decrease in cotton area. Cotton yield or any other economic characters, are influenced by the various agronomic treatments especially the planting in the late dates, irrigation method and fertilizer doses. Recently, the majority of farmers are delaying the recommended 
planting date for cotton to take the advantage of cultivating some winter crops before cotton such as clover. Moreover, the global warming occurred nowadays, which led to an increase in the temperature degrees.

Agriculture production strategy should be based on optimizing plant function in relation to environment to give high productivity with long-term stability. Temperature plays a dominate role in controlling metabolism, consequently growth and developmental rates of cotton plant. Reddy et al. (1991) recorded a 50\% decline in total shoot biomass for upland cotton plants grown under a $40 / 30^{\circ} \mathrm{C}$ day/night temperature regime as compared to plants grown under the optimal day/night temperature condition $\left(30 / 20^{\circ} \mathrm{C}\right)$. Reddy et al. (1995) studied the effects of carbon dioxide and temperature on pima cotton growth and they found that at $35.5^{\circ} \mathrm{C}$, little growth response to high $\mathrm{CO}_{2}$ environments occurred at $700 \mu \mathrm{ll}^{-1}$ $\mathrm{CO}_{2}$ compared with $350 \mu \mathrm{ll}^{-1} \mathrm{CO}_{2}$, but approximately about $45 \%$ increase occurred in the plants grown at 18.9-26. $9^{\circ} \mathrm{C}$. Arevalo (2008) suggested that high night temperatures increased the respiration rates, resulting in further depletion of carbohydrates as well as the yield. Loka and Oosterhuis (2010) showed that high night temperatures significantly increased respiration rates while photosynthesis rates remained unaffected which led to a perturbation in carbohydrate metabolism and might resulted in inefficient use of carbohydrates. In general, high night temperatures increased respiration, which resulted in a reduction of leaf ATP levels and leaf carbohydrate content.
Planting cotton in a suitable time leads to low first node, forming fruiting branches with an optimum height, increasing number of bolls and yield of cotton. In addition, it helps in escaping from leaf worms, boll worms and aphids at the end of the season and picking early. Ali and El-Sayed (2001) found that early sowing increased number of fruiting branches per plant. El-Hindi et al. (2006) found that early sowing in March increased yield and its components, i.e. number of open bolls per plant, boll weight, seed cotton yields per plant and fed. ${ }^{-1}$ in varieties related to (GossypiumbarbadenseL.). Zaheer et al. (2012) found that sowing on May $1^{\text {st }}$ produced the highest boll weight $(2.83 \mathrm{~g})$, seed cotton yield $\left(3032 \mathrm{~kg} \mathrm{ha}^{-1}\right)$. as compared with sowing in April and June. Batool et al. (2013) revealed that seed cotton yield was highly affected directly and indirectly both by boll number and boll weight in cotton.

Irrigation is essential to enhance crop production in arid climates. Irrigation is also practiced in humid and sub-humid climates to protect crops during periods of drought. Shaozhong et al. (2000) found that the most surprising result was that AFI maintained high grain yield with up to $50 \%$ reduction in irrigation amount, while FFI and CFI all showed a substantial decrease in yield with reduced irrigation. Pei-Ling et al. (2010) found that had no significant changes under alternative furrow irrigation on cotton yield. While, Ling and Cang (2011) showed that cotton yield was not significant different under the same water between alternative furrow irrigation and conven- 
tional furrow irrigation. James et al. (2014) found that irrigation induced variation in CT-heat units (11981416) similar to the decadal variation in AT-heat units (1270-1508). Two heat unit-based management tools: 1) the assignment of irrigation crop coefficients and 2) the identification of a fiber thickening period were both found to be sensitive to irrigationinduced changes in CT-heat unit accumulation. The inclusion of CT-heat units resulted in variability in both indicators that reflected effects of irrigation and climate on plant performance. Inclusion of canopy temperature measurements in heat unit accumulation might improve the utility of heat units. Wiggins et al. (2014) indicated that differences in physiological growth patterns occurred when compared across irrigation amounts. For example, they found that irrigation increased cotton plant vegetative biomass. Yang et al. (2015) showed that the growth varied with irrigation regime.

Reducing cost of production are essential aims for growers, but it usually depends on many factors especially that influence the plant growth. Nutrition manner is considered as one of the most important factors that affecting plant growth. Furthermore, NPK forms are the most important plant nutrients limiting plant growth and consequently yield, but higher levels may result in excessive of vegetative growth with a lower yield and quality. Dong et al. (2010) found that boll number and boll weight were affected by $\mathrm{N}, \mathrm{K}$ fertilization lower fertility field. Nitrogen fertilization increased boll number and $\mathrm{K}$ fertilization improved boll weight; a combination of $\mathrm{N}$ and $\mathrm{K}$ increased boll number, boll weight and yield. El-Shahawy and Hamoda (2011) obtained that number of fruiting branches/plant, number of open bolls per plant, boll weight and seed cotton yield per fed. increased by increasing nitrogen levels. Baraich et al. (2012) found that yield components (the number of bolls plant ${ }^{-1}$, seed cotton yield/plant and seed cotton yield $\mathrm{ha}^{-1}$ ) of cotton varieties were affected by different nitrogen levels at the highest rate $200 \mathrm{~kg} \mathrm{ha}^{-1}$ which produced 42.22 bolls plant ${ }^{-1}, 44.00 \mathrm{~g}$ seed cotton weight plant ${ }^{-1}$ and 1975 $\mathrm{kg}$ seed cotton yield ha ${ }^{-1}$. Seadh et al. (2012) found that number of fruiting branches/plant were significantly increased by increasing NPK rate from 25 up to $100 \%$ of the recommended rate at all sampling dates in both seasons. The rate of $100 \%$ NPK recorded the highest values of the mentioned traits, while the rate of $25 \%$ NPK recorded the lowest ones in both seasons.

Splitting of NPK participates in a continuous availability of nitrogen, phosphor and potassium as an essential element for cotton plants, which ensures better nutrition, reflected in better growth appearance. On the contrary, decreasing NPK doses leads to losing these elements beyond root zone without utilization by plants, especially at younger ages of growth. Srinivasan et al.(2001) and Mahmood et al. (2003) found that number of sympodia /plant affected significantly by split application of NPK fertilizer. Muhammad et al. (2014) revealed that all yield and yield parameters were significantly affected by split doses of different fertilizers as Nitro- 
gen, Phosphorous and Potassium (at sowing, after the removal cotton sticks and at booting stages). While, Bhati and Singh (2015) revealed that split application of $\mathrm{N}$ and NK did not have any significant effect on seed cotton yield, yield per plant, bolls per plant and boll weight.

\section{Materials and Methods}

The present investigation was carried out at Shandaweel Agric. Res. Station (Sohag governorate), A.R.C., Egypt during the two successive growing seasons of 2012 and 2013 to study the response of Egyptian cotton variety Giza-90 to alternative irrigation patterns with NPK fertilizer rates and frequencies under two plantings on cotton yield and its components. In each season, six separate field trials were done as a combination between three irrigation systems and two planting dates. Each experiment consists of three NPK levels distributed by two, three, four and five equal doses using complete randomized block design with split plot arrangement according to Gomez and Gomez (1984). The NPK levels were allocated to main plot and splitting was assigned to sub plots. Finally, combined analysis over all experiments in each season was done with the collected data after testing them with Bartlett's test for variance homogeneity following Snedecor and Cochran (1989). For comparison between means, Revised L.S.D. at 5\% level of probability was used following (Steel and Torrie 1981).

The experimental plot area was $25 \mathrm{~m}^{2}$ (5 m length and $5 \mathrm{~m}$ width). Each plot consisted of 8 rows, spacing between rows were about 60 $\mathrm{cm}$.
There were three irrigation systems as follows;

A. Conventional furrow irrigation CFI. It means that every furrow was irrigated during each watering.

B. Fixed two furrows irrigation FFI. It means that every two rows linked together from the two edges then water cannot inter between them during irrigation.

C. Alternate furrow irrigation AFI (new irrigation method). It means that every two rows linked together from the two edges in one irrigation and remove this link in the next irrigation and so on till the end of the experiment.

Each irrigation treatment was repeated in two planting dates i.e.,

A. Early planting date (on $20^{\text {th }}$ March)

B. Late planting date (on $20^{\text {th }}$ April). Under each planting date three rates of NPK fertilization were done as follows;

A. low rate $(75 \%)$ from the recommended, as 45, 16.9 and 18 NPK kg/fed, respectively.

B. Recommended rates $(100 \%)$, as $60,22.5$ and $24 \mathrm{NPK} \mathrm{kg} / \mathrm{fed}$, respectively.

C. High rates $(125 \%)$ from the recommended, as 75, 28 and $30 \mathrm{NPK} \mathrm{kg} / \mathrm{fed}$, respectively.

Each fertilization level was added as follows;

A. Two equal doses $\left(\mathrm{Sp}_{2}\right)$ were added before the second irrigation and the third irrigation.

B. Three equal doses $\left(\mathrm{Sp}_{3}\right)$ were being added before the second, the third and the fourth irrigation, respectively. 
C. Four equal doses $\left(\mathrm{Sp}_{4}\right)$ were being added before the second, the third, the fourth and the fifth irrigation, respectively.
D. Five equal doses $\left(\mathrm{Sp}_{5}\right)$ were being added before the second, the third, the fourth, the fifth and the sixth irrigation, respectively.

Table 1. Physical and chemical properties of the upper $60 \mathrm{~cm}$ of the experimental soil sites in2012 and 2013 seasons.

\begin{tabular}{|c|c|c|c|}
\hline \multicolumn{2}{|c|}{ Properties } & 2012 season & 2013 season \\
\hline \multirow{3}{*}{ Physical analysis } & Sand $\%$ & $19 \%$ & $21 \%$ \\
\hline & Silt & $48 \%$ & $51 \%$ \\
\hline & Clay & $33 \%$ & $28 \%$ \\
\hline Soil texture & \multicolumn{3}{|c|}{ Silt clay loam } \\
\hline \multirow{7}{*}{ Chemical analysis } & PH (1:1) & 7.66 & 7.60 \\
\hline & $\mathrm{CaCo3} \%$ & 3.88 & 3.90 \\
\hline & $\mathrm{Co}_{3} \& \mathrm{HCo}_{3} \mathrm{meq} / \mathrm{L}$ & 10.0 & 9.5 \\
\hline & $\mathrm{Na} \mathrm{meq} / \mathrm{L}$ & 2.36 & 2.09 \\
\hline & Total N \% & 1.6 & 1.8 \\
\hline & Total P (ppm) & 5.192 & 5.537 \\
\hline & Total K (ppm) & 223 & 231 \\
\hline
\end{tabular}

The above analysis was carried out in the Agricultural Research Center Soil, Water \& Environment Res. Institute Unit of Analysis \& Studies.

Here, it should be noted that daily of maximum and minimum temperature were recorded and the amounts of heat units scored were calculated in 30 days intervals through the cotton growing season (March to September) in 2012 and 2013 seasons for Shandweel Agricultural Station as shown in Table 2. Heat units were calculated according to Young et al. (1980) equation.

$\mathrm{HU}=$ Mean daily minimum and maximum Temperatures - K (zero point of growth $=12.8^{\circ} \mathrm{C}$ ).

Table 2. Meteorological data recorded at Sohag Governorate during the 2012 and 2013 seasons.

\begin{tabular}{|c|c|c|c|c|c|c|c|c|}
\hline \multirow{2}{*}{ Month } & \multicolumn{3}{|c|}{ Temperature in ${ }^{\circ} \mathbf{C}$ during 2012season } & \multicolumn{3}{c|}{ Temperature in ${ }^{\circ}$ during 2013 season } \\
\cline { 2 - 8 } & Max. & Min. & mean & $\begin{array}{c}\text { Total } \\
\text { H.U }\end{array}$ & Max. & Min & mean & $\begin{array}{c}\text { Total } \\
\text { H.U }\end{array}$ \\
\hline March & 26.5 & 7.8 & 17.1 & 133.3 & 9.1 & 24.6 & 16.9 & 127.1 \\
\hline April & 33.1 & 14.2 & 23.6 & 324 & 15.1 & 32.9 & 24.0 & 336 \\
\hline May & 34.8 & 16.7 & 25.8 & 403 & 19.6 & 35.8 & 27.7 & 461.9 \\
\hline June & 37.3 & 20.5 & 28.9 & 483 & 20.9 & 37.8 & 29.3 & 495 \\
\hline July & 38.1 & 20.4 & 29.2 & 508.4 & 21.9 & 38.1 & 30.0 & 533.2 \\
\hline August & 36.8 & 20.7 & 28.8 & 496 & 20.3 & 36.6 & 28.5 & 436.7 \\
\hline September & 33.5 & 17.5 & 25.5 & 381 & 17.5 & 34.8 & 25.7 & 387 \\
\hline Mean & 34.3 & 16.83 & 25.56 & 2728.7 & 17.77 & 34.38 & 26.01 & 2776.9 \\
\hline
\end{tabular}


Data recorded:

A. Yield and its components:

1- Number of sympodia branches /plant at harvest.

2- Number of open bolls/plant.

3-Average seed cotton yield in grams/plant.

4- Boll weight in grams: The average boll weight was estimated as follow:

Boll weight $=\frac{\text { Sged cottsn yiald/plant in gramg }}{\text { Number of harusted boll/plant }}$

5- Seed cotton yield/fed. in kentar.

Results and Discussion

1- Effect of planting dates on yield and its components:

Results presented in the Tables

3 to 12 revealed that the combined analysis for the two planting date in the two growing seasons 2012 and 2013significantly affected on yield and its component (number of sympodia / plant, number of open boll / plant, boll weight, seed cotton yields / plant and per fed.) which were increased in favor of earlier sowing. Early planting in March led to an increase in number of sympodia / plant (15.96 and 16.35), number of open boll / plant (17.07 and 17.16), boll weight (2.08 and 2.14), seed cotton yield per plant (35.63 and $36.81)$ and per fed. (8.16 \& 8.17) in 2012 and 2013 seasons, respective1y. Temperature plays a critical and complicated role in the growth and development of cotton as it helps early plants to have a longer period to flowering and this contributed so much in increasing the amount of metabolites synthesized by the plant, increasing the number of fruiting branches and number of open bolls per plant as well as the seed cotton yield. These results are in a good line with those obtained by El-Hindi et al. (2006) and Batool et al. (2013).

2- Effect of irrigation systems on yield and its components:

The results in the same Tables indicated that irrigated treatments had a significant effect on all the studied characters in both seasons. Irrigation of cotton plants with a new irrigation method, i.e. alternative irrigation system led to increase in number of open boll / plant and seed cotton yield / plant in the first and second planting date in the two growing seasons. Furthermore, boll weight and seed cotton yield / fed. in the first planting date for each seasons. On the other hand, irrigated treatment (conventional furrow irrigation) recorded the highest mean values for the boll weight and seed cotton yield / fed. in the second planting date in both seasons. Similar findings were obtained by Sheng et al. (2007) as it may be due to continuous stomatal inhibition and reduced leaf transpiration. Whereas, Ling and Cang (2011) showed that cotton yield was not significant different under the same water between alternative furrow irrigation and conventional furrow irrigation, cotton yield of conventional furrow irrigation was higher on average than the fixed every other furrow irrigation by $9.15 \%$. AFI takes advantage of this physiological response and exposes part of the root system alternatively to the drying soil.

3- Effect of NPK fertilizer rates on yield and its components:

Data presented in the same mentioned Tables indicated that increasing NPK level until $100 \%$ from the recommended significantly in- 
creased number of open bolls / plant and seed cotton yield / plant. This may be due to strong the vegetative growth and produced more from bolls/plant with increasing the period of vegetative growth and boll weight. This result is in harmony with that reported by Molin and Hugie (2010). While, adding $125 \%$ rates NPK from the recommended caused an increase in the number of sympodia / plant, boll weight and seed cotton yield / fed., as compared to $75 \%$ and $100 \%$ rates from the recommended. These results are in agreement with those obtained by El-Hindi et al. (2006).

\section{4- Effect of splitting of NPK ferti- lizer on yield and its components:}

It is clear that splitting fertilizers had a considerable effect on the productivity of cotton plant. The data proved that number of sympodia / plant tended to be increased as number of splitting was increased $\left(\mathrm{Sp}_{5}\right)$. Boll weight, seed cotton yields / plant and per fed. in the first planting date respond to a considerable fertilizer until $\mathrm{Sp}_{5}$. Whereas, number of open bolls / plant respond to $\mathrm{Sp}_{4}$ for each season. On the other hand, the second planting date respond to splitting fertilizers until $\mathrm{Sp}_{4}$ for number of open boll / plant, boll weight, seed cotton yields / plant and per fed. in 2012and 2013 seasons. Present results could be attributed to the best management of fertilizers through splitting N, P, K which may decrease the loss of leaching. These findings agreed with those obtained by Rasool et al. (2010) and Muhammad et al. (2014).

\section{5- Effect of the interactions on yield and its components:}

Results in Tables 3-12, revealed that the effect of interaction shown in tables 3-12 are described as follows: -

All the first order interactions had a significant effect on all characters in both seasons except,

a. Irrigation systems $\times$ NPK splitting interaction for No. open bolls/plant in both seasons, No. of sympodia / plant, boll weight and seed cotton yield/plant in the first season.

b. NPK rates $\times$ NPK splitting interaction for No. open bolls/plant, No. of sympodia/ plant and seed cotton yield/plant in both seasons, boll weight in the first season and seed cotton yield /fed. In the second season.

c. Irrigation systems $\times$ planting dates interaction for No. open bolls/plant in the first season.

d. NPK rates $\times$ planting dates interaction for No. open bolls/plant in both seasons.

For the second order interaction it was as follows

a. Irrigation systems $\times$ NPK rates $\times$ NPK splitting interaction had not significant effect on all characters except No. of sympodia / plant in the second season and seed cotton yield /fed. In the first season.

b. Irrigation systems $\times$ NPK rates xplanting dates interaction had significant effect on all studded characters.

c. Irrigation systems $\times$ NPK splitting $x$ planting dates interaction had a significant effect on No. of sympodi a/ plant and boll weight in the second season, No. open bolls/plant and seed cotton yield /fed. in first season. 
d. NPK rates $\times$ NPK splitting $\times$ planting dates interaction had no significant effect on all characters except No. of sympodia / plant in the second season and seed cotton yield/fed. In both seasons.

For the third order interaction, it had no significant effect on all characters except boll weight in the second season only.

\section{Conclusion}

Under the conditions of the present work, the alternative furrow irrigation, fertilizing $125 \%$ NPK from the recommended and splitting fertilizers to five equal splits gave the highest yield and its components.

\section{Reference}

Ali, S.A. and A.E. El-Sayed (2001). Effect of sowing dates and nitrogen levels on growth, earliness and yield of Egyptian cotton cultivar Giza-88. Egypt J. Agric. Res., 79(1): 221-232.

Arevalo, L.M. (2008). Physiological response of cotton to high night temperatures. Am. J. Plant Sci. and Bio, 2: 63-68.

Baraich, A.A.K.; A.H.K. Baraich; L.A. Jamali and A.U. Salarzi (2012). Effect of nitrogen application rates on growth and yield of cotton varieties. Pak. J. Agri. Eng. Vet. Sci., 28 (2): 115-123.

Batool S.; N.U. Khan; S. Gul; M.J. Baloch; N.A. Turi; S.A. Taran and M. Saeed (2013). Genetic analysis for yield and yield contributing variables in upland cotton. J. Food, Agr. Environ. 11(3\&4): 624-630.

Bhati, A.S. and M. Singh (2015). Effect of split application of nitrogen and potassium on yield, nutrient uptake and nutrient use efficiency in Bt cotton. Ann. of Plant and Soil Res. 17 (1): 71-73.
Dong, H.; X. Kong; W. Li; W. Tang and D. Zhang (2010). Effects of plant density and nitrogen and potassium fertilization on cotton yield and uptake of major nutrients in two fields with varying fertility. Field Crops Res., 119: 106-113.

El-Hindi, M.H.; E.M. Said; M.H. Ghonema and A.E. Khalifa (2006). Studies on the effect of some cultural practices on the growth and the yield of Egyptian cotton. J. Agric. Sci. Mansoura Univ., 31 (7): 4087-4095.

El-Shahawy, M.I.M. and S.A.F. Hamoda (2011).The proper agricultural management practices for the new promising hybrid cotton (Giza $77 \mathrm{x}$ Pima S6). J. plant production, Mansoura Univ., 2(11): 15511561.

Gomez, K.A. and A.A. Gomez (1984). Statistical Procedures for Agriculture Research.A Wiley-Inter Sci. Publication, John Wiley and Sons, Inc. New York, USA.

James, M.R.; M. Young; P. Payton; M. Bange and J. Stout (2014). Effect of differential irrigation on accumulation of canopy temperaturebased heat units in cotton. J. of Cotton Sci. 18:129-136.

Ling, L.P. and ZH.F.Cang (2011). Effect of regulation of water and nitrogen on cotton yield and water use efficiency under different furrow irrigation patterns. J. Cotton Sci., 23(1): 28-33.

Loka, D.A. and D.M. Oosterhuis (2010). Effect of high night temperatures on cotton respiration, ATP levels and carbohydrate content. Environmental and Experimental Botany $68: 258-263$.

Mahmood, ul-h.; T. Muhammed; M. Nasrullah; M. Jqbal; A. Nasir and I. Haq (2003).Cotton response to split application of nitrogen ferti- 
lizer. Asian J. of plant Sci., 2(6): $457-460$.

Molin, W. T. and J. A. Hugie (2010).Effects of Population Density and Nitrogen Rate in Ultra Narrow Row Cotton. S.R.X. Agric. V. 2010, Article $868723:(1-6)$.

Muhammad, A.; A.H. Sanghi; L. Khalid and Sh. Javed (2014). Demonstration and evaluation of the effect of time of application of NPK fertilizers on the yield of wheat in standing cotton. Int. J. Adv. Res. Bio. Sci., 1(3):74-80.

Pei-ling, L.; Z. Fu-cang and J. Yun-gang (2010). Coupling effect of water and nitrogen on population physiological indices under alternative furrow irrigation. Sci. Agric. Sinica.

Rasool, G.; T.H. Chattha and M.A. Ali (2010).Response of cotton (Gossypiumhirsutum $L$.) to various levels and times of potash application. J. Agric. Res., 48(1): 81-85.

Reddy, K.R.; H.F. Hodges and J.M. McKinion (1995). Carbon dioxide and temperature effects on pima cotton growth. Agric. Ecosyst. Environ. 54:17-29

Reddy, V.R.; D.N. Baker and H.F. Hodges (1991).Temperature effect on cotton canopy growth, photosynthesis and respiration. J. Agron. , 83: 699-704.

Seadh, S.E.; M.H. El-Hindi; H.A. Abd El-Aal and O.S.El- Shaimaa (2012). Effect of NPK rates and humic acid applications on growth of Egyptian cotton. J. Plant Production, Mansoura Univ., 3(8): 2287-2299.

Shaozhong, K.; Z. Lianga; Y. Pan; P. Shic and J. Zhang (2000). Alternate furrow irrigation for maize productionin on arid area. Agric. Water Management 45: 267-274.
Sheng, D.T.; K.Sh. Zhong; W.Zh. Chang; W. Feng; Y.X. Yingand and S.X. Li (2007). Responses of Cotton Growth, Yield, and Water Use Efficiency to Alternate Furrow Irrigation. J. Acta Agron. Sinica, 33(12):1982-1990.

Snedecor, G.W. and W.G. Cochran (1981). Statistical Methods. Seventh Ed. Iowa State Univ. Press, Ames, Iowa, USA.

Srinivasan, G.; N. Sivasamy and K. Venkatesan (2001).Studies on management practices for summer irrigated cotton genotypes. Madras Agric. J. 2001 publ 2002 ; 88(10/12): 689-690.

Steel, G.D. and J.H.Torrie, (1981) Principles and Procedures of Statistics (2nd edition) McGraw-Hill Book Company. Inc. N. Y. xxi-633pp.

Wiggins, M.S.; B.G. Leib; Th.C. Mueller and Ch.L. Main (2014).Cotton growth, yield and fiber quality response to irrigation and water deficit in soil of varying depth to a sand layer. J. of Cotton Sci., 18(2): 145-152.

Yang, C.J.; Y. Luo; L. Sun and N. Wu (2015).Effect of deficit irrigation on the growth, water use characteristics and yield of cotton in arid Northwest China. Pedosphere. 25(6): 910-924.

Young, E.F.; R.M. Teyler and H.D. Petarson (1980).Day-degree units and time in relation to vegetative development and fruiting for three cultivars of cotton. Crop Sci., 20: 370-375.

Zaheer, A.D.; S. Laghari; S. Abro; S.D. Anzada and F. Ddin (2012).Effect of sowing dates and picking intervals on boll opening percent, yield and fiber quality of cotton cultivars. Sci., Tech. and Dev., 31 (3): 288-293. 
دراسة القطن المصري لنظم الري التبادلي مع معدلات ومرات إضافة من

\section{NPK}

أحمد عيد محمود السيد"، السيد محمد محمود شلبي'، وجدي محمد عمر الثناذلي' و محمد ثروت سعيد'

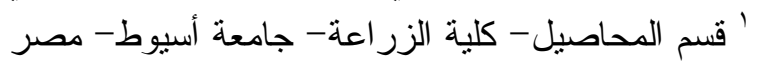

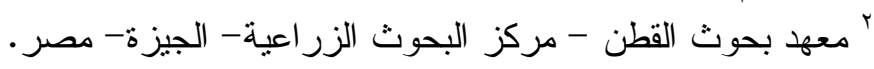

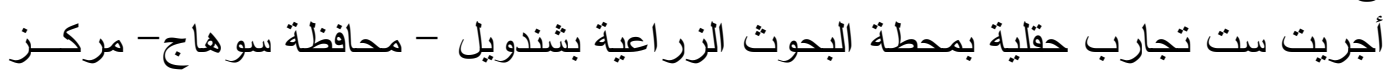

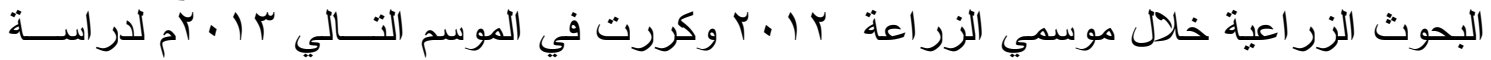

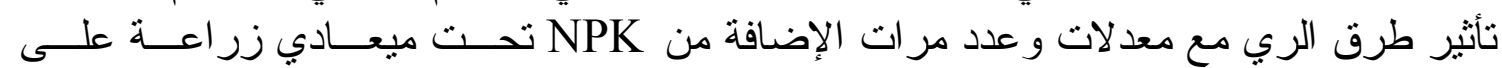

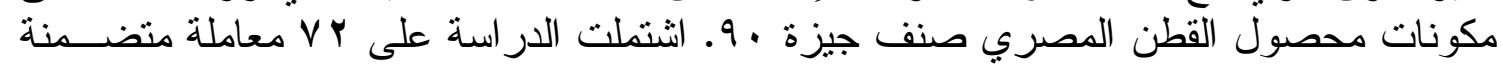

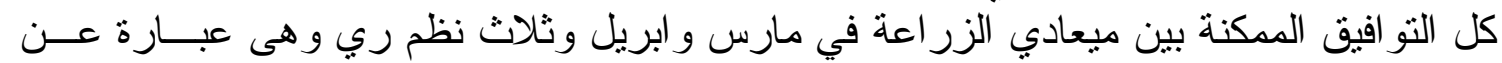

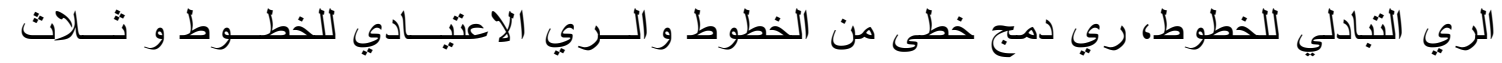

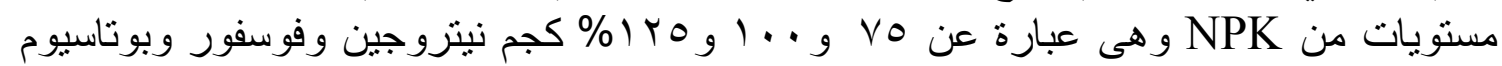

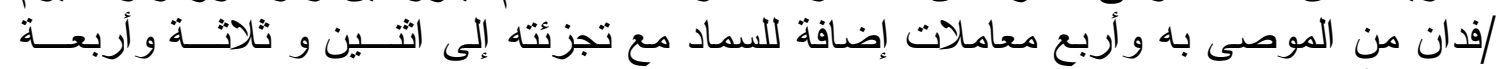
وخمسة أجز اء إضافة.

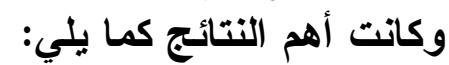

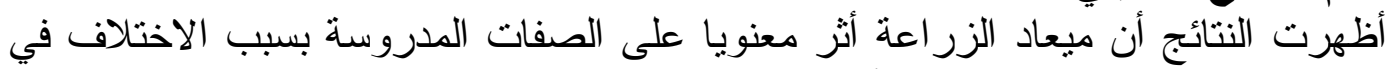

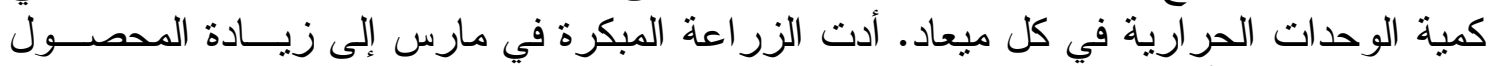

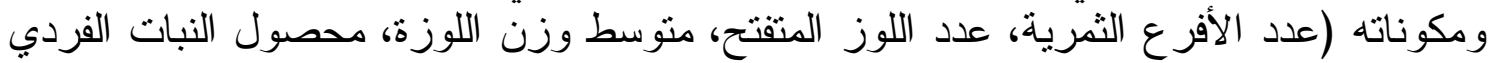

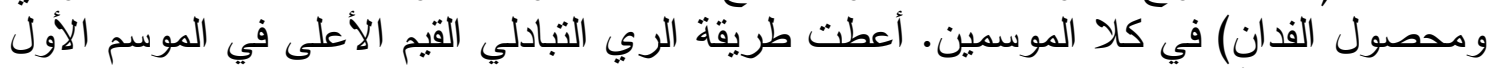

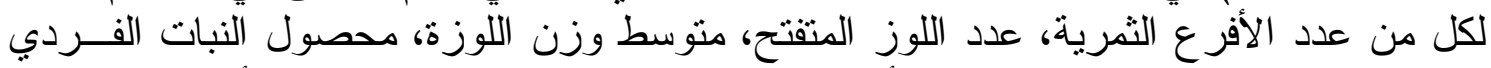

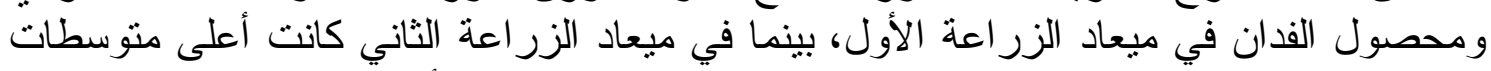

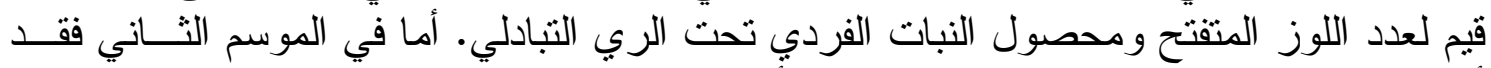

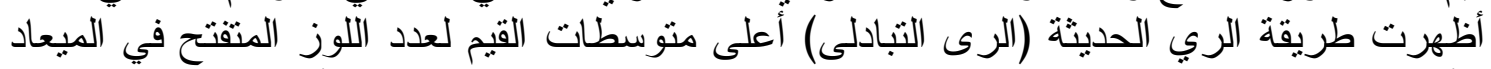

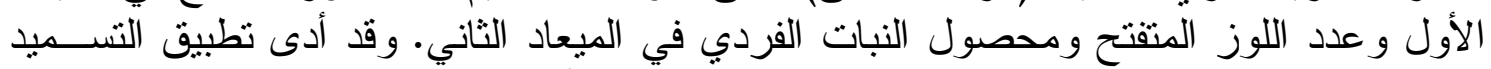

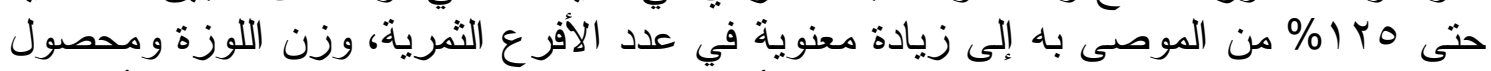

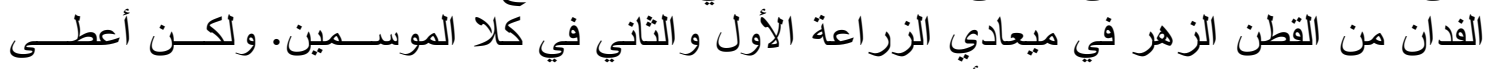

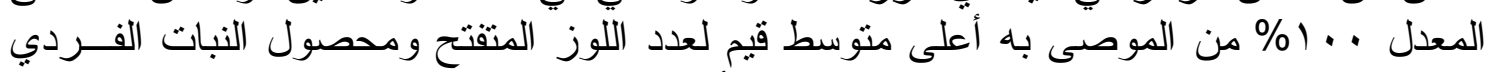

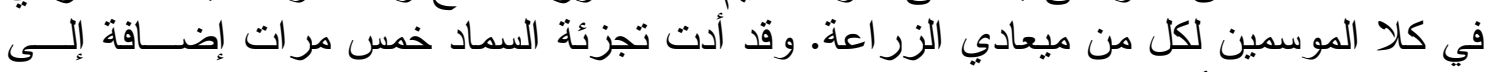

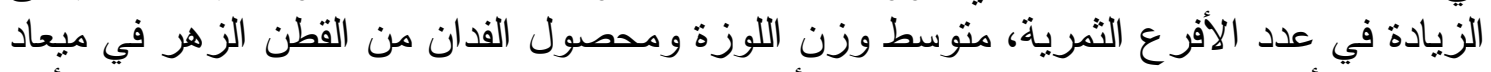

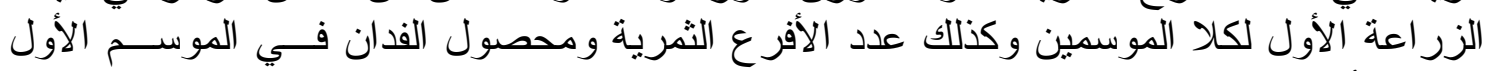

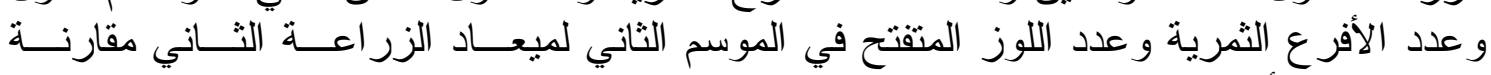
بالمعاملات الأخرى. 